Journal of Agriculture, Food and Environment (JAFE)

Journal Homepage: $\underline{\text { http://journal.safebd.org/index.php/jafe }}$

http://doi.org/10.47440/JAFE.2020.1418

Original Article

\title{
Storage effect on the moisture content (\%) and sensory quality parameters of silver carp (Hypophthalmichthys molitrix) fish noodles and consumers' preference to it
}

\author{
F. H. Shikha, M. I. Hossain* and L. Farzana \\ Department of Fisheries Technology, Bangladesh Agricultural University, Mymensingh-2202, Bangladesh
}

$\underline{\text { Article History }}$

Received: 16 November 2020

Revised: 09 December 2020

Accepted: 14 December 2020

Published online: 31 December 2020

\section{*Corresponding Author}

M. I. Hossain, E-mail: ihossain.ft@bau.edu.bd

\section{Keywords}

fish noodles, percent moisture content, sensory quality parameters, consumer's preference

\begin{abstract}
A B S T R A C T
Development of different fish products using boneless muscle is popular in this subcontinent. The present study was conducted to assess the changes in percent moisture content and sensory quality parameters of noodles prepared with silver carp mince along with wheat flour and to study the consumer's preference to the fish noodles. Silver carp fish mince and other ingredients were incorporated with wheat flour in substitution levels of $0,20,25$ and 30\%. The prepared noodles were oven dried, cooled and stored in polythene and vacuum sealed packs during storage at ambient temperature $\left(30\right.$ to $\left.35^{\circ} \mathrm{C}\right)$ for 6 months. During this storage period no remarkable change could be observed in the color, flavor, texture and taste of the noodle samples accept the moisture content of the samples. The percent moisture content of noodle samples slightly increased (i.e., percent moisture content increased from 6.37 to 12.38 in sealed polythene pack after 90 days of storage and to 10.02 in vacuum sealed pack after 180 days of storage in control noodle sample whereas in sample with $30 \%$ substitution level of fish mince the value increased from 11.94 to 13.44 in sealed polythene pack and to 12.88 in vacuum sealed pack after 90 days and 180 days of storage, respectively) with the lapse storage period. No mold growth could be found on noodle samples. Fish noodles prepared with $25 \%$ silver carp mince had the highest score 7.9 (out of 9) for taste though scores for the color (7.9), flavor (7.8), texture (8.1) and overall acceptability (8.4) were higher for the noodles prepared with $30 \%$ silver carp mince. Therefore, the study could be concluded as- fish noodles can be stored at room temperature for about 6 months in polythene pack and vacuum sealed packs without any major deterioration in sensory quality parameters accept little increase in moisture.
\end{abstract}

(C) Society of Agriculture, Food and Environment (SAFE)

\section{Introduction}

Consumer's demand is processed foods of high quality with minimal changes in nutritional and sensory properties (Ahvenainen, 2003). So, the goal of food manufacturers is to develop and employ processing technologies that retain or create desirable sensory qualities or reduce undesirable changes in food due to processing (Belcher, 2006). Many emerging technologies have the potential to extend the shelf life of the products (Nagarajarao, 2016). There is evidence that human have been processing fish since the early Holocene (Nielsen, 2003 and Zohar et al., 2001). In many developing countries, like Bangladesh, fish processing uses less-sophisticated methods of transformation, such as salting, smoking, drying and fermentation. However, in the last decade, fish processing has evolved also in many developing countries. At present context, value-added fish minced products will bring immediate benefit to the existing fish processing industries in Bangladesh (Nowsad, 1994). In recent year's value addition have received a wider attention because of increased urbanization. There is a growing demand for value-added products due to social and cultural changes (Pagarkar et. al., 2011). Therefore, development of value added products from low cost fish could be a profitable era of supplying processed fish products to Bangladesh market.

Bangladesh is a riverine country and there are a wide variety of fish species available here. Among these various species of fishes silver carp is one of the most common, popular and cheapest species of fish. Since last few years different types of value-added fish products are available in super shops of the country but preparing noodles using silver carp mince seems an unique idea. If silver carp mince is incorporate with 
wheat flour to prepare noodles, a percent of animal protein will also be consumed along with carbohydrate by the consumers in a tasty and easy way. The people who eat less fish, specially people of young age, fish protein can be given to them through a product like fish noodle. Therefore, preparation of fish noodles might be an addition to the protein enriched food manures to the consumers. Considering this point, attempts were taken to prepare fish noodles using silver carp fish mince. After preparing noodles, they were stored in sealed polythene and vacuum sealed packs at room temperature $\left(30\right.$ to $\left.35^{\circ} \mathrm{C}\right)$ to observe the changes in the moisture content and sensory quality parameters of the noodle samples

\section{Materials and Methods}

The study was carried out in the laboratories of the department of Fisheries Technology, of Bangladesh Agricultural University, Mymensingh from December 2016 to September 2017 (total 10 months).

\section{Materials}

To prepare noodles with the help of a vertical noodle maker, required amount of fresh silver carp fish, wheat flour and other major ingredients (salt, oil, different spices) were bought from the local market.

\section{Methods \\ Preparation of silver carp mince}

The fish mince was prepared from fresh fish samples which were collected from the local market. First of all, the fishes were cut by discarding the head, fins, tail, and viscera and washed with clean water. The fish was then boiled for 8-10 minutes. After boiling the boiled pieces were deboned manually to separate the fleshes. The skin and oil also were separated from the fleshes the fleshes were packed in a plastic container and stored in a refrigerator until further use.

\section{Formulation of Noodles}

The formulation of fish noodles is presented in Table- 1 . The wheat flour was replaced with 0, 20, 25 and $30 \%$ of silver carp mince in the formulation $\mathrm{C}$ (noodles without fish mince), S1 (noodles prepared with $20 \%$ fish mince), S2 (noodles prepared with $25 \%$ fish mince), S3 (noodles prepared with $30 \%$ fish mince), respectively.

Table 1. Basic formulation of $100 \mathrm{~g}$ noodles with wheat flour and silver carp mince

\begin{tabular}{lcccc}
\hline \multirow{2}{*}{\multicolumn{1}{c}{ Ingredients }} & \multicolumn{4}{c}{ Samples } \\
\cline { 2 - 5 } & $\mathbf{C}$ & S1 & S2 & S3 \\
\hline Wheat flour $(\mathrm{g})$ & 100 & 80 & 75 & 70 \\
\hline Silver carp mince $(\mathrm{g})$ & 0 & 20 & 25 & 30 \\
\hline Water $(\mathrm{ml})$ & 40 & 40 & 40 & 40 \\
\hline Oil $(\mathrm{ml})$ & 5 & 5 & 5 & 5 \\
\hline Salt $(\mathrm{g})$ & 2 & 2 & 2 & 2 \\
\hline Spices $(\mathrm{g})$ & .5 & .5 & .5 & .5 \\
\hline
\end{tabular}

${ }^{*} \mathrm{C}=$ control noodles with wheat flour only; $\mathrm{S} 1=$ noodles with $80 \%$ wheat flour, $20 \%$ silver carp mince; $\mathrm{S} 2=$ noodles with $75 \%$ wheat flour, $25 \%$ silver carp mince; $\mathrm{S} 3=$ noodles with $70 \%$ wheat flour, $30 \%$ silver carp mince.

\section{Preparation of noodles}

As presented in Table-1, all the ingredients such as wheat flour, silver carp mince, salt, oil and spices were weighed. To prepare dough, the ingredients were mixed with warm water and kneaded for 10 minute. The prepared dough was transferred to a vertical noodles making machine and longer types of noodles were made. The prepared noodles were then oven-dried (at $60^{\circ} \mathrm{C}$ ) for $4 \mathrm{hrs}$

\section{Storage of noodles}

The dried and cooled noodles were divided into two parts; one part was sealed in polethene packs (Plate-1. a) and another part was sealed in vacuum sealed packs (Plate-1. b). Including the control one all the noodle samples were stored at ambient temperature $\left(30-35^{\circ} \mathrm{C}\right)$ and relative humidity $(\mathrm{RH})$ of $80-88 \%$ for a period of 6 months. During storage the change in percent moisture content, color, flavor, texture, taste, overall acceptability and mold growth on noodles were investigated.
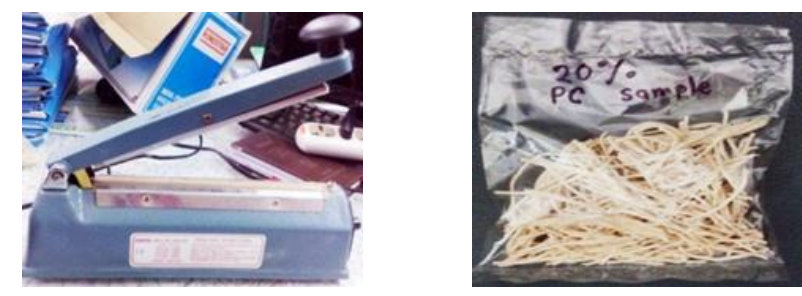

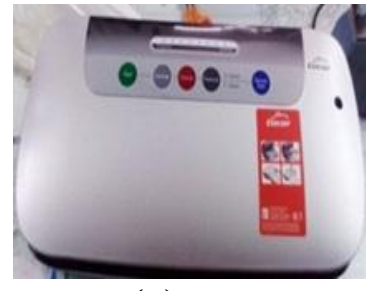

(a)

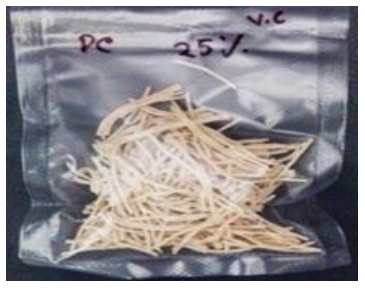

(b)
Plate 1. (a) Sealer and noodles sample sealed in plastic pack and (b) Vacuum sealer and samples in vacuum sealed pack

\section{Percent moisture content and sensory parameters}

The percent moisture content of the samples was determined following AOAC (2005) method. The sensory parameters of prepared noodles was evaluated by a testing panel. The hedonic rating test was used to determine the acceptability. It is the most widely used scale for measuring food acceptability. It is also called the 9 point hedonic test. Jones et. al. (1955) showed that longer scale to nine intervals tended to be more discriminating than shorter scale.

The panelists were chosen from different social status. The panelists rated their acceptability of the product on a 01-09 point hedonic scale. The scale was arranged such that $9=$ like extremely, $7=$ like very much, $6=$ like slightly, $5=$ neither like nor dislike, $4=$ dislike slightly, $2=$ dislike very much and $1=$ dislike extremely.

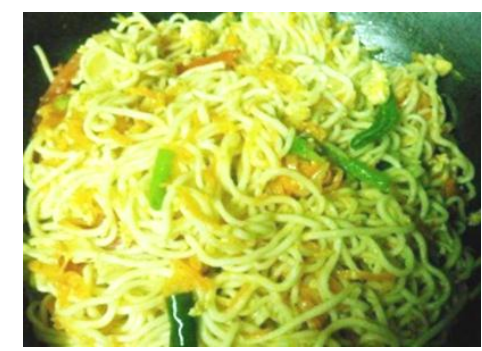

Plate 2. Cooked noodles for sensory evaluation by consumers 
Shikha et al., 2020

\section{Results}

Percent moisture content and sensory parameters

The percent moisture content of four noodle samples gradually increased both in sealed polythene packs and vacuum sealed packs throughout the storage. The color, flavor, texture, taste and overall acceptability of the noodle samples also changed with the lapse of storage period though the change was negligible. Table- 2 shows the changes in percent moisture content and sensory quality parameters of prepared fish noodle samples during storage at ambient temperature in sealed polythene packs and vacuum sealed packs.

Table 2. Changes in percent moisture content and sensory quality parameters of fish noodles during storage at ambient temperature $\left(30\right.$ to $35^{\circ} \mathrm{C}$ ) both in sealed polythene pack and vacuum sealed pack

\begin{tabular}{|c|c|c|c|c|c|c|c|c|c|c|c|c|c|c|c|c|}
\hline \multirow[t]{3}{*}{ Temperature } & \multirow{3}{*}{$\begin{array}{c}\begin{array}{c}\text { Days } \\
\text { of } \\
\text { storage }\end{array} \\
\end{array}$} & \multirow{3}{*}{$\begin{array}{l}\text { Types of } \\
\text { Noodles }\end{array}$} & \multicolumn{14}{|c|}{ Observation } \\
\hline & & & \multicolumn{2}{|c|}{ Moisture (\%) } & \multicolumn{2}{|c|}{ Color } & \multicolumn{2}{|c|}{ Flavor } & \multicolumn{2}{|c|}{ Texture } & \multicolumn{2}{|c|}{ Taste } & \multicolumn{2}{|c|}{ Mold growth } & \multicolumn{2}{|c|}{ Remarks } \\
\hline & & & $\begin{array}{c}\text { Sealed } \\
\text { pack }\end{array}$ & $\begin{array}{c}\text { Vacuum } \\
\text { sealed } \\
\text { pack }\end{array}$ & $\begin{array}{c}\text { Sealed } \\
\text { pack }\end{array}$ & $\begin{array}{c}\text { Vacuum } \\
\text { sealed } \\
\text { pack }\end{array}$ & $\begin{array}{c}\text { Sealed } \\
\text { pack }\end{array}$ & $\begin{array}{c}\text { Vacuum } \\
\text { sealed } \\
\text { pack }\end{array}$ & $\begin{array}{c}\text { Sealed } \\
\text { pack }\end{array}$ & $\begin{array}{c}\text { Vacuum } \\
\text { sealed } \\
\text { pack }\end{array}$ & $\begin{array}{c}\text { Sealed } \\
\text { pack }\end{array}$ & $\begin{array}{c}\text { Vacuum } \\
\text { sealed } \\
\text { pack }\end{array}$ & $\begin{array}{c}\text { Sealed } \\
\text { pack }\end{array}$ & $\begin{array}{c}\text { Vacuum } \\
\text { sealed } \\
\text { pack }\end{array}$ & $\begin{array}{c}\text { Sealed } \\
\text { pack }\end{array}$ & $\begin{array}{c}\text { Vacuum } \\
\text { sealed } \\
\text { pack }\end{array}$ \\
\hline & 0 & $\begin{array}{l}\text { C } \\
\text { S1 } \\
\text { S2 } \\
\text { S3 }\end{array}$ & $\begin{array}{c}6.37 \\
9.91 \\
10.9 \\
11.94\end{array}$ & $\begin{array}{c}6.37 \\
9.91 \\
10.9 \\
11.94\end{array}$ & $\begin{array}{l}\text { Very } \\
\text { Good }\end{array}$ & $\begin{array}{l}\text { Very } \\
\text { Good }\end{array}$ & $\begin{array}{l}\text { Very } \\
\text { Good }\end{array}$ & $\begin{array}{l}\text { Very } \\
\text { Good }\end{array}$ & Crispy & Crispy & $\begin{array}{l}\text { Very } \\
\text { Good }\end{array}$ & $\begin{array}{l}\text { Very } \\
\text { Good }\end{array}$ & No & No & $\begin{array}{l}\text { Very } \\
\text { Good }\end{array}$ & $\begin{array}{l}\text { Very } \\
\text { Good }\end{array}$ \\
\hline & 15 & $\begin{array}{l}\text { C } \\
\text { S1 } \\
\text { S2 } \\
\text { S3 }\end{array}$ & $\begin{array}{c}7.67 \\
11.02 \\
11.33 \\
12.20\end{array}$ & & $\begin{array}{l}\text { Very } \\
\text { Good }\end{array}$ & & $\begin{array}{l}\text { Very } \\
\text { Good }\end{array}$ & & Crispy & & $\begin{array}{l}\text { Very } \\
\text { Good }\end{array}$ & & No & & $\begin{array}{l}\text { Very } \\
\text { Good }\end{array}$ & \\
\hline & 30 & $\begin{array}{l}\text { C } \\
\text { S1 } \\
\text { S2 } \\
\text { S3 }\end{array}$ & $\begin{array}{c}8.13 \\
11.42 \\
11.65 \\
12.45\end{array}$ & $\begin{array}{c}7.01 \\
10.02 \\
11.06 \\
12.08 \\
\end{array}$ & $\begin{array}{l}\text { Very } \\
\text { Good }\end{array}$ & $\begin{array}{l}\text { Very } \\
\text { Good }\end{array}$ & $\begin{array}{l}\text { Very } \\
\text { Good }\end{array}$ & $\begin{array}{l}\text { Very } \\
\text { Good }\end{array}$ & Crispy & Crispy & $\begin{array}{l}\text { Very } \\
\text { Good }\end{array}$ & $\begin{array}{l}\text { Very } \\
\text { Good }\end{array}$ & No & No & $\begin{array}{l}\text { Very } \\
\text { Good }\end{array}$ & $\begin{array}{l}\text { Very } \\
\text { Good }\end{array}$ \\
\hline & 45 & $\begin{array}{l}\text { C } \\
\text { S1 } \\
\text { S2 } \\
\text { S3 } \\
\end{array}$ & $\begin{array}{c}9.23 \\
11.78 \\
11.94 \\
12.27 \\
\end{array}$ & & $\begin{array}{l}\text { Very } \\
\text { Good }\end{array}$ & & $\begin{array}{l}\text { Very } \\
\text { Good }\end{array}$ & & Crispy & & $\begin{array}{l}\text { Very } \\
\text { Good }\end{array}$ & & No & & $\begin{array}{l}\text { Very } \\
\text { Good }\end{array}$ & \\
\hline \multirow[t]{6}{*}{$\begin{array}{l}\text { Ambient } \\
\text { temperature } \\
\left(30-35^{\circ} \mathrm{C}\right)\end{array}$} & 60 & $\begin{array}{l}\text { C } \\
\text { S1 } \\
\text { S2 } \\
\text { S3 }\end{array}$ & $\begin{array}{l}10.08 \\
12.01 \\
12.23 \\
12.98\end{array}$ & $\begin{array}{c}7.42 \\
10.11 \\
11.18 \\
12.20\end{array}$ & $\begin{array}{l}\text { Very } \\
\text { Good }\end{array}$ & $\begin{array}{l}\text { Very } \\
\text { Good }\end{array}$ & $\begin{array}{l}\text { Very } \\
\text { Good }\end{array}$ & $\begin{array}{l}\text { Very } \\
\text { Good }\end{array}$ & Crispy & Crispy & $\begin{array}{l}\text { Very } \\
\text { Good }\end{array}$ & $\begin{array}{l}\text { Very } \\
\text { Good }\end{array}$ & No & No & $\begin{array}{l}\text { Very } \\
\text { Good }\end{array}$ & $\begin{array}{l}\text { Very } \\
\text { Good }\end{array}$ \\
\hline & 75 & $\begin{array}{l}\text { C } \\
\text { S1 } \\
\text { S2 } \\
\text { S3 }\end{array}$ & $\begin{array}{l}11.22 \\
12.34 \\
12.56 \\
13.16\end{array}$ & & $\begin{array}{l}\text { Very } \\
\text { Good }\end{array}$ & & $\begin{array}{l}\text { Very } \\
\text { Good }\end{array}$ & & Crispy & & Good & & No & & $\begin{array}{l}\text { Very } \\
\text { Good }\end{array}$ & \\
\hline & 90 & $\begin{array}{l}\mathrm{C} \\
\mathrm{S} 1 \\
\mathrm{~S} 2 \\
\mathrm{~S} 3\end{array}$ & $\begin{array}{l}12.38 \\
12.77 \\
12.89 \\
13.44 \\
\end{array}$ & $\begin{array}{c}8.11 \\
10.22 \\
11.39 \\
12.39 \\
\end{array}$ & $\begin{array}{l}\text { Very } \\
\text { Good }\end{array}$ & $\begin{array}{l}\text { Very } \\
\text { Good }\end{array}$ & $\begin{array}{l}\text { Very } \\
\text { Good }\end{array}$ & $\begin{array}{l}\text { Very } \\
\text { Good }\end{array}$ & Crispy & Crispy & Good & $\begin{array}{l}\text { Very } \\
\text { Good }\end{array}$ & No & No & $\begin{array}{l}\text { Very } \\
\text { Good }\end{array}$ & $\begin{array}{l}\text { Very } \\
\text { Good }\end{array}$ \\
\hline & 120 & $\begin{array}{l}\text { C } \\
\text { S1 } \\
\text { S2 } \\
\text { S3 }\end{array}$ & & $\begin{array}{c}8.78 \\
10.35 \\
11.46 \\
12.49\end{array}$ & & $\begin{array}{l}\text { Very } \\
\text { Good }\end{array}$ & & $\begin{array}{l}\text { Very } \\
\text { Good }\end{array}$ & & Crispy & & $\begin{array}{l}\text { Very } \\
\text { Good }\end{array}$ & & No & & $\begin{array}{l}\text { Very } \\
\text { Good }\end{array}$ \\
\hline & 150 & $\begin{array}{l}\text { C } \\
\text { S1 } \\
\text { S2 } \\
\text { S3 }\end{array}$ & & $\begin{array}{c}9.34 \\
10.55 \\
11.67 \\
12.61\end{array}$ & & $\begin{array}{l}\text { Very } \\
\text { Good }\end{array}$ & & $\begin{array}{l}\text { Very } \\
\text { Good }\end{array}$ & & Crispy & & Good & & No & & $\begin{array}{l}\text { Very } \\
\text { Good }\end{array}$ \\
\hline & 180 & $\begin{array}{l}\mathrm{C} \\
\mathrm{S} 1 \\
\mathrm{~S} 2 \\
\mathrm{~S} 3\end{array}$ & & $\begin{array}{l}10.02 \\
10.98 \\
11.92 \\
12.88\end{array}$ & & $\begin{array}{l}\text { Very } \\
\text { Good }\end{array}$ & & $\begin{array}{l}\text { Very } \\
\text { Good }\end{array}$ & & Crispy & & Good & & No & & Good \\
\hline
\end{tabular}

$* \mathrm{C}=\mathrm{Control}$ noodles with wheat flour; $\mathrm{S} 1=80 \%$ wheat flour, $20 \%$ silver carp mince $; \mathrm{S} 2=75 \%$ wheat flour, $25 \%$ silver carp mince ; $\mathrm{S} 3=$ $70 \%$ wheat flour, $30 \%$ silver carp mince.

As shown in Table-2 it was observed that at ambient temperature $\left(30-35{ }^{\circ} \mathrm{C}\right)$ and a relative humidity of 80 to $88 \%$ the moisture content of control noodle samples varied from $6.37 \%$ to $12.38 \%$ while stored in sealed polythene packs within 90 days whereas the value ranged from $6.37 \%$ to $10.02 \%$ for the noodle samples stored in vacuum sealed pack during the storage of 180 days. On the other hand, in the case of S3 (30\% silver carp mince incorporated noodles) the range of moisture content varied from $11.94 \%$ to $13.44 \%$ in sealed polythene pack and $11.94 \%$ to $12.88 \%$. in vacuum sealed pack. For other two noodle samples also a similar increasing trend in moisture content (\%) was observed with the progress of storage period though the rate of increment was faster and higher for the samples stored in sealed polythene pack.

The color, flavor, texture, taste and overall acceptability of the prepared noodle samples were also monitored. Investigation was carried out at each 15 days of interval of the samples stored in sealed polythene pack and the samples stored in vacuum sealed packs was examined at each 30 days of interval. No remarkable change of color, flavor, texture and taste was observed in any of the packed noodles samples. The color and flavor of the noodles remained good and the texture was found crispy even after 90 days of storage in sealed polythene pack and 180 days of storage in vacuum sealed pack. The growth of mold on the noodle samples was also monitored. No mold growth could be found during the storage period of 90 days in sealed pack or 180 days in vacuum sealed pack.

In this study it was observed that the percent moisture content of noodle samples increased both in sealed polythene pack and vacuum sealed pack though the level of increment was comparatively higher in sealed polythene packs. Jalgaonkar et al. (2017) carried out a study on quality changes in pearl millet based pasta during storage in flexible packaging at ambient condition $32.95 \pm 8.75{ }^{\circ} \mathrm{C}(\max )$ for 6 months. In their study the moisture content (MC) of pasta varied from $8.87 \%$ to $11.90 \%$ which trend is quite similar to 
the findings of present study. The loss or gain of moisture through a package depends on the sorption isotherm of the food material, the conditions of temperature and relative humidity at which it is stored, and the water vapour permeability of the packaging material (Cardoso and Labuza; 1983). The water vapour permeability (WVP) characteristics of paperboard, polypropylene, and polyethylene used for pasta were determined at 30 to $45^{\circ} \mathrm{C}$ and from 11 to $85 \%$ r.h. Both temperature and relative humidity affected the water vapour permeability of all the three films. This statement explains the reason of higher increment of percent moisture of noodles in sealed polythene pack than vacuum sealed packs.

Gull et al. (2016) studied the quality changes in functional pasta during storage in two different packaging materials: LDPE and BOPP for 4 months. In their study they observed significant change in moisture content and color but the overall acceptability of products remained good even after 4 months of storage on the basis of determined parameters. These findings are more or less similar to the present study.

\section{Consumer's preference to fish noodles}

A survey was continued for one month (November) in the year 2017 on the acceptability of fish noodle by the consumers. The data was collected from different stake holders of the Faculty of Fisheries and Kamal-Ranjit Market by using a previously prepared questionnaire. The categories and distribution of the selected characteristic of consumer's are shown in Table-3 and the result of different consumer's responses (category wise) are presented in Figure 1(a, b and c). The color, flavor, texture, taste and overall acceptability score given by the consumers (10 persons) are presented in Table-4.Taste testing was conducted separately by an expert panel (10 persons) and the result is presented in Table-5.

From Table-3 and Figure-1 (a, b, and c) it was observed that-people of adult age (44\%) liked the fish noodles than the people of other age groups. While noodles was offered consumer's education wise the graduate or educated above graduation people liked it most $(41 \%)$, then it was liked by people who were higher secondary passed (36\%). On the other hand among the people from different occupations, business men liked the offered noodles less (9\%) than the government/non-government service holders or teachers.

Table 3. Categories and distribution of the selected characteristics of consumers'

\begin{tabular}{|c|c|c|c|}
\hline Variable & $\begin{array}{c}\text { Observed } \\
\text { range }\end{array}$ & $\begin{array}{c}\text { Possible } \\
\text { range }\end{array}$ & Categories \\
\hline \multirow{3}{*}{ Age } & \multirow{3}{*}{$16-55$} & \multirow{3}{*}{ Year } & Young age (15-30) \\
\hline & & & Adult age (31-50) \\
\hline & & & Old age $(>50)$ \\
\hline \multirow{4}{*}{ Education } & \multirow{4}{*}{$5-18$} & \multirow{4}{*}{$\begin{array}{c}\text { Year of } \\
\text { schooling }\end{array}$} & Primary $(1-5)$ \\
\hline & & & Secondary (6-10) \\
\hline & & & Higher secondary \\
\hline & & & Graduate/above \\
\hline \multirow{3}{*}{ Occupation } & \multirow{3}{*}{$1-4$} & \multirow{3}{*}{$\begin{array}{c}\text { Type of } \\
\text { occupation }\end{array}$} & Service \\
\hline & & & Businessman \\
\hline & & & Teacher \\
\hline
\end{tabular}

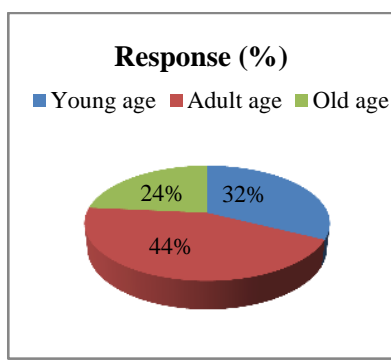

(a)

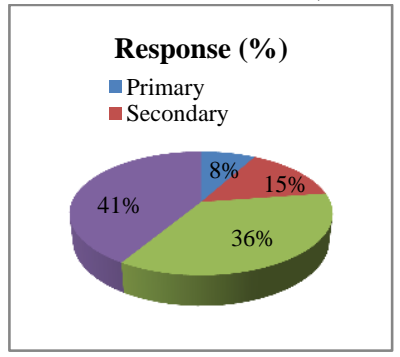

(b)

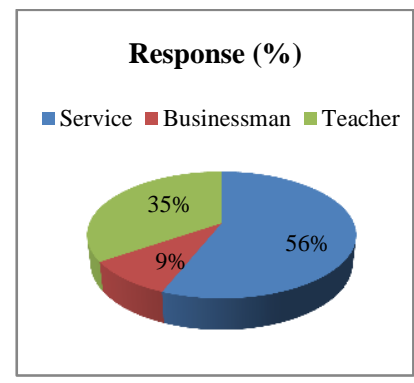

(c)

Figure 1. Consumer's response (\%) to fish noodles according to (a) age, (b) education and (c) occupation

The mean of the scores given by the consumers for color, flavor, texture and overall acceptability (Table-4) shows that- among 4 noodles samples $(\mathrm{C}=$ control noodles with wheat flour only; S1= noodles with $80 \%$ wheat flour, $20 \%$ silver carp mince; $\mathrm{S} 2=$ noodles with $75 \%$ wheat flour, $25 \%$ silver carp mince; S3=noodles with $70 \%$ wheat flour, $30 \%$ silver carp mince) the color, flavor, texture and overall acceptability were highest for sample 3 and lowest for sample C. The scores varied for different samples among the consumers but none of the samples received score below 6 indicating that he noodles samples were liked by the consumers.

Table 4. The color, flavor, texture, taste and overall acceptability score given by the consumers

\begin{tabular}{|c|c|c|c|c|c|c|c|c|c|c|c|c|c|c|c|c|}
\hline \multirow[t]{3}{*}{ Consumer } & \multicolumn{16}{|c|}{ Samples and Sensory Parameters } \\
\hline & \multicolumn{4}{|c|}{ Color } & \multicolumn{4}{|c|}{ Flavor } & \multicolumn{4}{|c|}{ Texture } & \multicolumn{4}{|c|}{$\begin{array}{c}\text { Overall } \\
\text { acceptability }\end{array}$} \\
\hline & $\mathbf{C}$ & S1 & S2 & S3 & $\mathbf{C}$ & S1 & S2 & S3 & $\mathbf{C}$ & S1 & S2 & S3 & & S1 & $\mathbf{S 2}$ & S3 \\
\hline 1 & 7 & 7 & 8 & 9 & 7 & 6 & 6 & 7 & 7 & 7 & 7 & 7 & 7 & 7 & 8 & 9 \\
\hline 2 & 6 & 8 & 7 & 8 & 6 & 6 & 7 & 8 & 8 & 8 & 7 & 8 & 6 & 8 & 7 & 8 \\
\hline 3 & 6 & 7 & 7 & 8 & 7 & 7 & 8 & 8 & 7 & 7 & 6 & 8 & 6 & 7 & 7 & 8 \\
\hline 4 & 6 & 6 & 7 & 7 & 7 & 7 & 7 & 7 & 6 & 7 & 8 & 7 & 8 & 8 & 6 & 8 \\
\hline 5 & 7 & 7 & 8 & 7 & 7 & 7 & 7 & 9 & 7 & 6 & 7 & 9 & 7 & 6 & 7 & 9 \\
\hline 6 & 7 & 9 & 8 & 8 & 6 & 8 & 7 & 8 & 6 & 7 & 7 & 8 & 6 & 7 & 7 & 8 \\
\hline 7 & 7 & 8 & 8 & 7 & 6 & 8 & 6 & 7 & 7 & 7 & 8 & 9 & 7 & 7 & 7 & 9 \\
\hline 8 & 6 & 8 & 7 & 9 & 7 & 8 & 7 & 9 & 8 & 8 & 7 & 9 & 6 & 8 & 7 & 9 \\
\hline 9 & 7 & 7 & 8 & 8 & 7 & 7 & 8 & 8 & 7 & 7 & 8 & 8 & 7 & 7 & 7 & 8 \\
\hline 10 & 8 & 7 & 8 & 8 & 7 & 7 & 8 & 7 & 6 & 6 & 7 & 8 & 6 & 6 & 7 & 8 \\
\hline Total & 68 & 75 & 74 & 79 & 67 & 71 & 71 & 78 & 69 & 70 & 72 & 81 & 66 & 71 & 70 & 84 \\
\hline Mean & 6.8 & 7.5 & 7.4 & 7.9 & 6.7 & 7.1 & 7.1 & 7.8 & 6.9 & 7.0 & 7.2 & 8.1 & 6.6 & 7.1 & 7.0 & 8.4 \\
\hline
\end{tabular}

*C= control noodles with wheat flour only; $\mathrm{S} 1=$ noodles with $80 \%$ wheat flour, $20 \%$ silver carp mince; S2= noodles with $75 \%$ wheat flour, $25 \%$ silver carp mince; $\mathrm{S} 3=$ noodles with $70 \%$ wheat flour, $30 \%$ silver carp mince.

*Hedonic rating score: $9=$ like extremely, $8=$ like very much, $7=$ like moderately, $6=$ like slightly, $5=$ neither like nor dislike, $4=$ dislike slightly, $3=$ dislike moderately, $2=$ dislike very much, $1=$ dislike extremely. 
While the study was carried out for taste (Table-5 and Figure-2) by the panel members it was intestinally observed that- the mean score for taste was highest $(27 \%)$ for $\mathrm{S}-2$ (S2 $=75 \%$ wheat flour, $25 \%$ silver carp mince) though the highest score for color, flavor, texture and overall acceptability was found for S 3 (S3=70\% wheat flour, 30\% silver carp mince). In this case also Sample C (Control noodles with wheat flour) scored lowest (24\%) indicating that- incorporation of fish mince with wheat flour to prepare noodles increased the taste, improved the color, flavor, texture and overall acceptability.

Table 5. The score for taste of the noodles given by panel members

\begin{tabular}{ccccc}
\hline Panel member & \multicolumn{4}{c}{ Scores } \\
\cline { 2 - 5 } No. & $\mathbf{C}$ & $\mathbf{S}_{\mathbf{1}}$ & $\mathbf{S}_{\mathbf{2}}$ & $\mathbf{S}_{\mathbf{3}}$ \\
\hline Member 1 & 7 & 7 & 9 & 8 \\
\hline Member 2 & 7 & 7 & 8 & 7 \\
\hline Member 3 & 7 & 6 & 7 & 6 \\
\hline Member 4 & 7 & 7 & 8 & 7 \\
\hline Member 5 & 7 & 8 & 8 & 8 \\
\hline Member 6 & 7 & 8 & 8 & 7 \\
\hline Member 7 & 7 & 8 & 8 & 8 \\
\hline Member 8 & 7 & 7 & 7 & 7 \\
\hline Member 9 & 7 & 7 & 8 & 6 \\
\hline Member 10 & 7 & 7 & 8 & 7 \\
\hline Total & $\mathbf{7 0}$ & $\mathbf{7 2}$ & $\mathbf{7 9}$ & $\mathbf{7 2}$ \\
\hline Mean & $\mathbf{7 . 0}$ & $\mathbf{7 . 2}$ & $\mathbf{7 . 9}$ & $\mathbf{7 . 2}$ \\
\hline
\end{tabular}

${ }^{*} \mathrm{C}=\mathrm{C}$ Control noodles with wheat flour; $\mathrm{S} 1=80 \%$ wheat flour, $20 \%$ silver carp mince; S2 $=75 \%$ wheat flour, $25 \%$ silver carp mince; $\mathrm{S} 3=70 \%$ wheat flour, $30 \%$ silver carp mince

*Hedonic rating score: $9=$ like extremely, $8=$ like very much, 7 = like moderately, $6=$ like slightly, $5=$ neither like nor dislike, $4=$ dislike slightly, 3 = dislike moderately, 2 = dislike very much, 1 = dislike extremely

In this study to know the consumer's preference to prepared noodles a questioner was developed and gone through interview process. Bercelon et al (2014) carried out their study on consumer preference and sensory acceptability of vegetable-added pasta noodles through an open access online document composed of eight questions in total. Gathering information on some food products from some group of people through questioner interview either directly or indirectly is similar as done in both studies. Chung et al. (2010) also studied noodle consumption patterns of American consumers: NHANES 2001-2002. Their study was aimed to analyze the food consumption and diet patterns of noodle consumers and non-consumers according to age, gender, income, and ethnicity. The result of their study showed that- by age, the intake of noodles in the age range of 9-18 years old ranked highest at $353.0 \mathrm{~g}$, followed by the order of 19-50 year-olds with $333.5 \mathrm{~g}, 51-70$ year-olds with by $280.4 \mathrm{~g}$, older than 71 years old with $252.3 \mathrm{~g}$, and 1-8 year-olds with $221.5 \mathrm{~g}$. The study result also showed that, according to income, the intake amount for the middleincome level (PIR 1 1.85) of consumers was highest at 312.5 g. Noodle intake also showed different patterns by ethnicity in which the "other" ethnic group consumed the most noodles with $366.1 \mathrm{~g}$, followed by, in order, Hispanics with $318.7 \mathrm{~g}$, Whites with $298.6 \mathrm{~g}$, and Blacks with $289.5 \mathrm{~g}$. In the present study also to study the consumers preference to fish noodles age, education, occupation of the consumers were considered and the result showed that- consumer's preference to a food is influenced by these factors which is quite similar to the above findings.

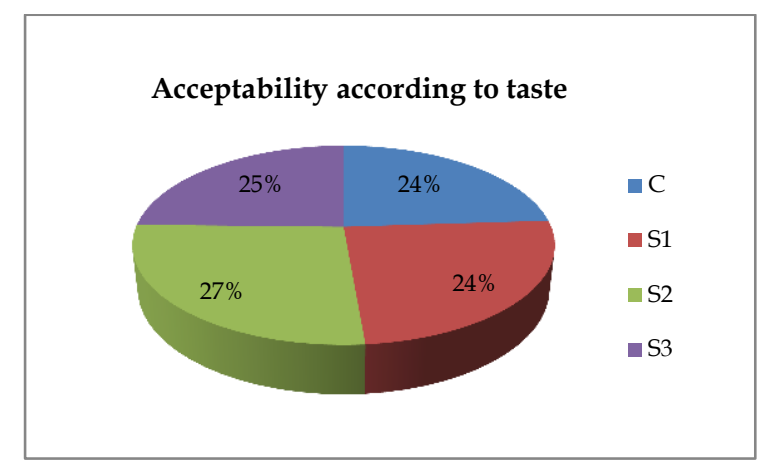

Figure-2. Acceptability of the noodles according to taste testing score given by the panel members

$* \mathrm{C}=$ Control noodles with wheat flour; $\mathrm{S} 1=80 \%$ wheat flour, $20 \%$ silver carp mince; $\mathrm{S} 2=75 \%$ wheat flour, $25 \%$ silver carp mince; $\mathrm{S} 3=70 \%$ wheat flour, $30 \%$ silver carp mince

\section{Conclusions}

No remarkable change in color, flavor, texture, taste and mold growth in the prepared noodles were observed up to 90 days (for sealed polythene pack) and 180 days (for vacuum sealed pack) of storage at ambient temperature $\left(30-35^{\circ} \mathrm{C}\right)$ and a relative humidity of $80-88 \%$. The observation on the change in percent moisture content in noodles showed a little increase in values, indicating the acceptability of the noodles for 90 days in sealed pack and 180 days in vacuum sealed pack. This study has demonstrated that the addition of silver carp mince had a remarkable influence on the sensory properties of noodles. Noodles prepared with $25 \%$ silver carp mince had the highest score for taste though scores for the color, flavor, texture and overall acceptability were observed higher for the noodles prepared with $30 \%$ silver carp mince along with wheat flour.

\section{Acknowledgement}

This research was funded by Bangladesh Agricultural University Research System

\section{References}

Ahvenainen R (2003). Novel Food Packaging Techniques. Woodhead Publishing Ltd. Cambridge. UK.

AOAC (2005). Official Methods of Analysis. Association of Official Analytical Chemists International, $18^{\text {th }}$ edition, Washington (D.C).

Barcelon GE, Chua JN, Encinas JB, Montemayor JE, Nagalinngam MG, Ocampo AE, Ong R MG (2014). Online Consumer Preference and Sensory Acceptability of Vegetable-Added Pasta Noodles. Food and Public Health 4(6): 301-305. doi: 10.5923/j.fph.20140406.07.

Belcher JN (2006), Industrial Packaging Developments for the Global Meat Market. Meat Science 74: 143-148.

Cardoso G and Labuza TP (1983). Prediction of moisture gain and loss for packaged pasta subjected to a sine wave temperature/humidity environment. International Journal Of Food Science and Technology 18 (5):587-606.

Chung CE, Lee KW, Cho MS (2010). Noodle consumption patterns of American consumers: NHANES 2001-2002. Nutrition Research and Practice 4(3):243-51.

Gull A, Prasad K, Kumar P (2016). Quality changes in functional pasta during storage in two different 
Shikha et al., 2020

packaging materials: LDPE and BOPP. Journal of Food Processing and Preservation 41(5): e13115.

Jalgaonkar K, Jha SK, Nain L, Iquebal MA (2017). Quality changes in pearl millet based pasta during storage in flexible packaging. Journal of Agricultural Engineering 54(3):22-31.

Jones LV, Peryam DR, Thurstone LL (1955). Development of a scale for measuring soldiers' food preferences. Food Research 20:512-520.

Nielsen TB (2003). Ancient Fishing and Fish Processing in the Black Sea Region. Aarhus University Press, Langelandsgade 177, DK-8200. pp. 222.
Ngarajarao RC (2016). Recent Advances in Processing and Packaging of Fishery Products: A Review. Aquatic Procedia 7 201-213.

Pagarkar AU, Joshi VR, Baug TE, Kedar JG (2011). Value addition is need of seafood industries. Fishery Cooperative 23(4) 8-14.

Zohar I, Dayan T, Galili E, Spanier E (2001). Fish Processing During the Early Holocene: A Taphonomic Case Study from Coastal Israel. Jour of Archeological Science 28(10):1041-1053. 